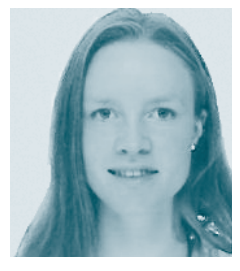

Kristin Lundanes Jonvik, Universitetet i Oslo og

Utviklingssenter for sykehjem

i Oslo, Abildsø sykehjem

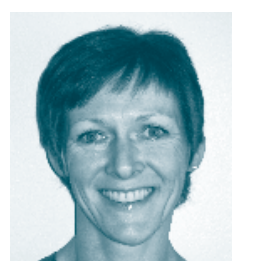

Randi Sørland, Utviklingssenter for sykehjem i Oslo, Abildsø sykehjem og Langerud sykehjem

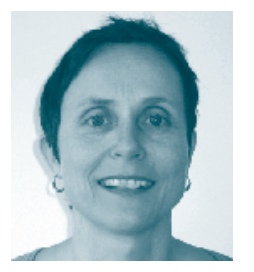

Torunn Wibe, Utviklingssenter for sykehjem i Oslo, Abildsø sykehjem www.sykepleien.no

Les mer og finn litteraturhenvisninger på våre nettsider.

\section{Søkeord:}

) Geriatri

) Sykehjem

) Ernæring

, Underernæring

\title{
Spiste flere måltider
}

\author{
Tilbud om ekstramåltider i sykehjem bidro til \\ at beboere med ernæringsproblemer spiste mer.
}

denne artikkelen ønsker vi å dele våre erfaringer fra et prosjekt for å bedre eldres ernæringssituasjonen i en sykehjemsavdeling. Det viste seg at de beboerne som ble kategorisert som underernærte ved MNA-screening, også var de som i størst grad takket ja til ekstra måltider når de fikk tilbud om det. Ikke alle disse ville ha bedt om ekstra mat på eget initiativ, noe som illustrerer at selv om beboerne ikke spør om mat kan det godt hende behovet er der.

\section{Bakgrunn}

De eldste er mest utsatt for å utvikle ernæringsproblemer. Særlig de som er syke, har demens og de eldste på institusjon, er i risikogruppen for å utvikle underernæring (1). Pasientene i institusjon er mer utsatt for underernæring enn personer som bor hjemme $(2,3)$.

Sykdom er den viktigste årsaken til underernæring. Underernæring øker risikoen for komplikasjoner, reduserer motstand mot infeksjoner, forverrer fysisk og mental funksjon, gir redusert livskvalitet, forsinket rekonvalesens og økt dødelighet (4). Underernæring defineres som en ernæringssituasjon der mangel på

\section{De eldste er mest utsatt for å utvikle ernoeringsproblemer.}

energi, protein og/eller andre næringsstoffer forårsaker en målbar ugunstig effekt på kroppssammensetning og -funksjon (5). Nøkkelen til en ernæringsmessig god pleie av institusjonsbeboere er at man oppdager vekttap tidlig, og at man overvåker næringsinntaket og ernæringsstatus kontinuerlig.

\section{MNA}

Ved det sykehjemmet hvor vi gjennomførte vårt prosjekt var det gjort ernæringsscreening og antropometriske målinger, som mål av høyde og vekt. Målingene viste at ernæringsstatusen generelt ikke var så god. Det var store variasjoner i BMI, med et gjennomsnitt på 24. Dette er i underkant av normalområdet for BMI hos eldre, som er foreslått å være på 24-29 kg/m² (6). Det var også utført en ernæringsscreening ved bruk av Mini Nutritional Assessment (MNA). MNA er et av verktøyene Helsedirektoratet har anbefalt for å kartlegge ernæringsstatus og ernæringsmessig risiko (4). MNA anbefales brukt for eldre over 65 år (7). Det viste seg at 65 prosent av beboerne ble vurdert til å ha risiko for underernæring. Det var derfor grunn til å iverksette tiltak for å bedre situasjonen.

Hensikten med dette prosjektet var å kartlegge avdelingens ernæringsrutiner og etablere nye skriftlige rutiner som inkluderte tiltak for å fange opp ernæringsstatus, optimalisere måltidsrytme og redusere antall beboere som hadde risiko for underernæring.

\section{Nye rutiner}

Prosjektet ble gjennomført i mars og april 2010 ved en langtidspost i et sykehjem i Oslo med 23 beboere. Innledningsvis ble avdelingens ernæringsrutiner kartlagt. Ut fra denne kartleggingen ble det utarbeidet forslag til skriftlige rutiner for å bedre ernæringssituasjonen for beboerne.

Det ene tiltaket var å innføre systematisk kartlegging av ernæringsstatusen til alle beboerne, ved hjelp av MNA. I tillegg ble det innført skriftlig rutine i forbindelse med månedlig veiing av alle beboerne for raskere å fange opp endringer i ernæringsstatus. Det andre tiltaket var å tilrettelegge måltidssituasjonen for å optimalisere næringsinntaket. Det var behov for å forkorte nattfasten med tanke på å øke totalt energiinntak og redusere antall pasienter i risiko for underernæring. For å redusere antall timer nattfaste, ble det innført tilbud om individuell tidligfrokost og/ eller senkveldsmat for alle beboere. Vektmåling, måltidstilbudet og responsen skulle registreres i Gerica, som er det elektroniske journalsystemet som brukes ved sykehjemmet.

\section{Kartlegging}

Ved å kartlegge ernæringsrutiner ved prosjektstart oppdaget vi at det ikke ble gjort noen form for ernæringsscreening rutinemessig, at det var mangelfulle rutiner for veiing av beboerne og at nattfasten var på opptil 15,5 timer. MNA-screening, som ble gjort av pleiepersonale som del av prosjektet, viste at 78 prosent av beboerne hadde ernæringsmessig risiko, hvorav 26 prosent ble kategorisert som underernærte. De fleste beboerne ble veid en gang i måneden under prosjektperioden.

\section{Ekstra måltider}

Det varierte ganske mye hvor godt de tre gruppene på avdelingen klarte å gjennomføre tiltaket med systematisk å tilby beboerne senkvelds (fra henholdsvis 44 prosent til 19 prosent av dagene 


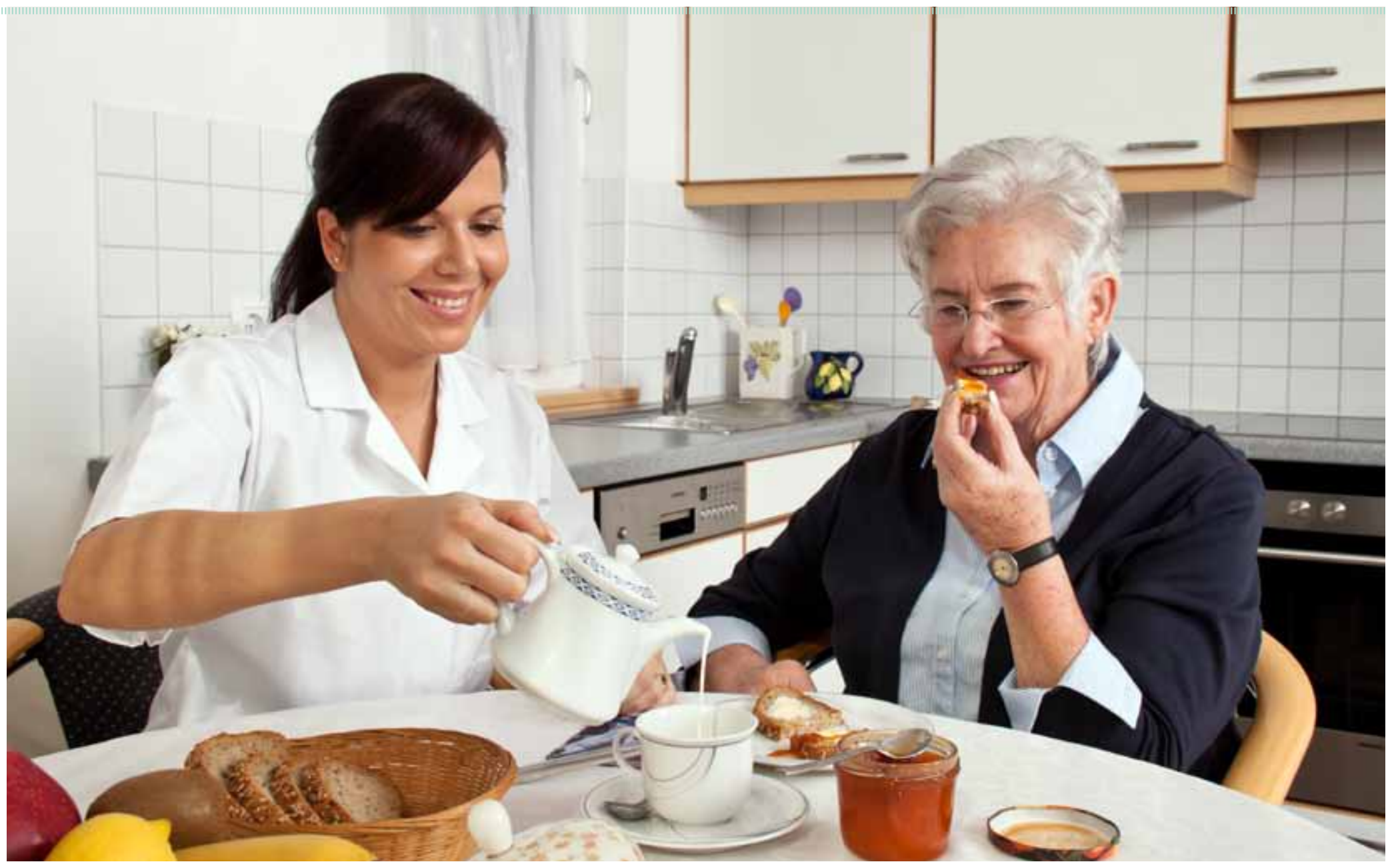

i prosjektperioden) og tidligfrokost (fra 16 prosent til 1 prosent av dagene). Gjennomsnittlig ble beboerne tilbudt senkvelds 30 prosent av dagene og tidligfrokost 7 prosent av dagene i prosjektperioden.

Det varierte også hvor mange som spiste ekstramåltider, men gjennomsnittlig takket beboerne ja til 30 prosent av de tilbudene om senkvelds som ble gitt i prosjektperioden. Av de 23 beboerne var det 13 stykker som takket ja til senkvelds. Tilsvarende ble det takket ja til cirka halvparten av tilbudene om tidligfrokost som ble gitt i perioden. Som det framgår i det foregående ble imidlertid tidligfrokost tilbudt i mindre grad enn senkvelds. Det var bare seks av beboerne som spiste tidligfrokost i løpet av prosjektperioden.

Et interessant funn var at de underernærte takket oftere ja til ekstra måltider enn resten av beboerne. De underernærte takket ja til 65 prosent av tilbudene om senkvelds, mens det for alle pasientene til sammen ble takket ja til 36 prosent av tilbudene om senkvelds.

\section{Diskusjon}

At de underernærte takker oftere ja til tilbud om ekstramåltider kan være et tegn på at manglende etterspørsel ikke alltid skal tolkes som at behovet eller ønsket om mat ikke er der. De underernærte, som kanskje har mest behov for ekstra mat, kan være blant de som først kjenner at de har lyst på noe når de får tilbudet.

Lav registreringsrate sier noe om hvor vanskelig det kan være å etablere nye rutiner. Det er derfor viktig at personalet jevnlig blir minnet på at de skal tilby ekstra måltider i starten (gjerne i forbindelse med vaktrapporten). En annen grunn til lav registrering kan være at det ikke er godt nok lagt til rette for å registrere ernæringstiltak i Gerica.

Personalet syntes MNA-screeningen var enkel å gjennomføre. De så på screeningen som et bra verktøy for å kategorisere beboerne, men mente at det må brukes litt skjønn og at beboerens vekt og allmenntilstand må tas med i vurderingen når tiltak skal

iverksettes. De syntes også rutinen for månedlig veiing av beboerne gikk veldig greit.

Personalet uttrykte at det var greit å tilby servering av både tidligfrokost og senkvelds. De mente imidlertid at det ikke var noen forskjell fra tidligere, hvor de som har ønsket mat utenom måltidene har fått det. De mente også at de kjenner beboerne så godt at de vet hvem som ønsker ekstra måltider. Personalet mente også at de beboerne, som hadde gitt uttrykk for at de ikke ønsket ekstra måltid tidligere, ble litt lei av å bli spurt hver dag. Disse faktorene bidro til at det ikke ble registrert tilbud av ekstra måltider hver dag for hver beboer. Beboerne som takket ja til tilbudet om tidligfrokost og senkvelds fikk oftest servert brødskiver, frukt og kjeks.

\section{Konklusjon}

Blant eldre er det mange som ikke kjenner sultfølelse i så stor grad som tidligere, og tilbud om senkvelds eller tidligfrokost kan derfor trigge lysten på mat. Selv om man i praksis tilbyr ekstra måltider til beboerne som ytrer ønsker om det, vil systematiske tiltak for å redusere nattfasten sikre et tilbud også til dem som ikke på eget initiativ ber om ekstra mat. III

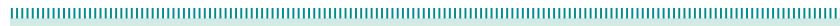

\section{LITTERATUR}

Arvanitakis M, Beck A, Coppens P, D MF, Elia M, Hebuterne X, et al. Nutrition in care homes and home care: how to implement adequate strategies. Clin Nutr 2008; 27(4): 481-8.

2. Guigoz Y. The Mini Nutritional Assessment (MNA) review of the literatureWhat does it tell us? J Nutr Health Aging 2006; 10(6): 466-85.

van Wayenburg CA, van de Lar FA, van WC van Staveren WA van Binsberen Nutritional deficiency in bergen Janstaveren WA, Van Bnsgeneral practice: a systematic review. Eur J Clin Nutr 2005, 59 Suppt 1: $81-$

Helsedirektoratet. Nasjonale retnings-
GIR MATLYST: Tilbud om senkvelds eller tidligfrokost for beboere på sykehjem kan trigge lysten på mat. Illustrasjonsfoto: Colourbox linjer for forebygging og behandling av underernæring. 2009.

Lochs H, Allison SP, Meier R, Pirlich M, Kondrup J, Schneider S, et al. Introductory to the ESPEN Guidelines on Entera Nutrition: Terminology, definitions and general topics. Clin Nutr 2006; 25(2): $180-6$

6. Beck AM, Ovesen L. At which body mass index and degree of weight loss should hospitalized elderly patients be considered at nutritional risk? Clin Nutr 1998 17(5): 195-8.

Kondrup J, Allison SP, Elia M, Vellas B, Plauth M. ESPEN guidelines for nutri22(4): 415-21. 2002.Clin Nutr 2003; 22(4): 415-21. 